$$
\text { CONF-780431- } 4
$$

\title{
Plasma-Wall Impurity Experiments in ISX-A
}
R. J. Colchin
C. E. Bush
P. H. Edmonds
A. C. England
K. W. Hill
R. C. Isler
T. C. Jernigan
P. W. King
R. A. Langley

D. H. McNeill

M. Murakami

R. V. Neidigh

G. H. Neilson

J. E. Simpkins

J. B. Wilgen

J. C. DeBoo

K. H. Burrell

E. S. Ensberg

\section{MASTER}

\section{OAK RIDGE NATIONAL LABORATORY} OPERATED BY UNION CARBIDE CORPORATION · FOR THE DEPARTMENT OF ENERGY 


\section{DISCLAIMER}

This report was prepared as an account of work sponsored by an agency of the United States Government. Neither the United States Government nor any agency Thereof, nor any of their employees, makes any warranty, express or implied, or assumes any legal liability or responsibility for the accuracy, completeness, or usefulness of any information, apparatus, product, or process disclosed, or represents that its use would not infringe privately owned rights. Reference herein to any specific commercial product, process, or service by trade name, trademark, manufacturer, or otherwise does not necessarily constitute or imply its endorsement, recommendation, or favoring by the United States Government or any agency thereof. The views and opinions of authors expressed herein do not necessarily state or reflect those of the United States Government or any agency thereof. 


\section{DISCLAIMER}

Portions of this document may be illegible in electronic image products. Images are produced from the best available original document. 
Printed in the United States of America. Available from National Technical Information Service

U.S. Department of Commerce

5285 Port Royal Road, Springfield, Virginia 22161

Price: Printed Copy $\$ 4.96$; Microfiche $\$ 3.00$

This report was prepared as an account of work sponsored by an agency of the United States Government. Neither the United States Government nor any agency thereof, nor any of their employees, contractors, subcontractors, or their employees, makes any warranty, express or implied, nor assumes any legal liability or responsibility for any third party's use or the results of sucl i use ul any infumation, apparatus, product or process disclosed in this report, nor represents that its use by such third party would not infringe privately owned rights. 
R. J. Colchin, C. E. Bush, P. H. Edmonds, A. C. England, K. W. Hill, R. C. Isler, T. C. Jernigan, P. W. King, R. A. Langley, D. H. McNeill, M. Murakami, R. V. Neidigh, G. H. Neilson, J. E. Simpkins, and J. B. Wilgen

Oak Ridge National Laboratory Oak Ridge, Tennessee and

J. C. DeBoo, K. H. Burrell, and E. S. Ensberg General Atomic Company San Diego, California

Date Published: August 1978

Prepared by the OAK RIDGE NATIONAL LABORATORY Oak Ridge, Tennessee 37830 operated by UNION CARBIDE CORPORATION for the DEPARTMENT OF ENERGY
This repor NoTICE This report was prepared as an account of work sponsored by the United States Government. Neither the
United States nor the United States Department of Energy, nor any of their employees, nor any of their contractors, subcontractors, or their employees, makes any warranty, express of implied, or assumes any legal
liability or responsibility for the accuracy, completeness liability or responsibility for the accuracy, completeness process disclosed, or represents that its use would not process disclosed, or represents
infringe privately owned rights.

\section{$==$}




\section{THIS PAGE}

WAS INTENTIONALLY

LEFT BLANK 
CONTENTS

ABSTRACT . . . . . . . . . . . . . . . . . . . v v

1. INTRODUCTION . . . . . . . . . . . . . . . . . 1

2. DESCRIPTION OF EXPERIMENTAL CONDITIONS . . . . . . . . . . 2

3. VACUUM CONDITIONS, $\mathrm{z}_{\text {eff }}$, AND RECYCLING . . . . . . . . . . 2

4. LIMITER EXPERIMENTS . . . . . . . . . . . . . . . . . 9

5. CONCLUSIONS . . . . . . . . . . . . . . . . . . 12

ACKNOWLEDGMENTS . . . . . . . . . . . . . . . . . 12

REFERENCES . . . . . . . . . . . . . . . . . . 13 
THIS PAGE

\section{WAS INTENTIONALLY LEFT BLANK}




\section{ABSTRACT}

The ISX-A was a tokamak designed for studying plasma-wall interactions and plasma impurities. It fulfilled this role quite well, producing reliable and reproducible plasmas which had currents up to $175 \mathrm{kA}$ and energy containment times up to $30 \mathrm{msec}$. With discharge precleaning, $\mathrm{Z}_{\text {eff }}$ was as low as 1.6; with titanium evaporation, $z_{\text {eff }}$ approached 1.0. Values of $z_{\text {eff }} \geq 2.0$ were found to be proportional to residual impurity gases in the vacuum system immediately following a discharge. However, there was no clear dependence of $\mathrm{Z}_{\text {eff }}$ on base pressure. Stainless steel limiters were used in most of the ISX-A experiments. When carbon limiters were introduced into the vacuum system, $Z_{\text {eff }}$ increased to 5.6. After twelve days of cleanup with tokamak discharges, during which time $Z_{\text {eff }}$ steadily decreased, the carbon limiters tended to give slightly higher values of $z_{\text {eff }}$ than stainless steel limiters. Injection of $<10^{16}$ atoms of tungsten into discharges caused the power incident on the wall to double and the electron temperature profile to become hollow. 


\section{INTRODUCTION}

ISX-A :(Impurity Study Experiment) ${ }^{l}$ was an iron core tokamak with a major radius of $92 \mathrm{~cm}$ and a minor radius of $26 \mathrm{~cm}$. This machine was designed for the study of plasma-wall interactions and plasma impurities. The bulk of the data taken from ISX-A was recorded during a 12-week period between December 12, 1977 and March 5, 1978. Stainless stee1 limiters were used except during the last two weeks of operation, when retractable molybdenum and carbon limiters were added. Upon completion of the experimental program, ISX-A was converted to ISX-B with the addition of neutral beams, a new vacuum vessel, and a new poloidal field system.

The principal experiments carried out during the lifetime of ISX-A can be broadly classified as the impurity flow reversal experiment, ${ }^{2}$. confinement studies, and surface physics studies. ${ }^{3}$ The confinement studies were conducted under a broad range of impurity and limiter conditions. In addition, tungsten limiters were simulated by using a laser blowoff system to puff tungsten into the plasma. The results of the confinement experiments, which are described in Sects. 3 and 4, are related to studies in several other tokamaks. ${ }^{4-9}$

Typical values of several plasma parameters are listed in Table 1 for sequences employing stainless steel and carbon limiters. The optimum plasma parameters achieved are given in the last column of Table 1 , but these parameters were not all achieved during the same discharge sequence.

Table 1. ISX-A plasma parameters

\begin{tabular}{lccc} 
& $\begin{array}{c}\text { Stainless steel } \\
\text { limiter }\end{array}$ & Carbon limiter & Optimum \\
\hline $\mathrm{B}_{\mathrm{T}}(\mathrm{kG})$ & 13.2 & 13.2 & 14.8 \\
$\mathrm{I}_{\mathrm{p}}(\mathrm{kA})$ & 120 & 116 & 175 \\
$\mathrm{q}\left(\mathrm{a}_{\ell}\right)$ & 4 & 4 & 2.5 \\
$\mathrm{n}_{\mathrm{e}}(0)\left(10^{13} \mathrm{~cm}^{-3}\right)$ & 5.2 & 4.0 & 9 \\
$\mathrm{~V}(\mathrm{v})$ & 1.5 & 1.5 & 0.9 \\
$\mathrm{~T}_{\mathrm{e}}(0)(\mathrm{keV})$ & 0.69 & 0.82 & 1.5 \\
$\mathrm{~T}_{i}(0)(\mathrm{keV})$ & 0.42 & 0.39 & 0.55 \\
$\mathrm{~T}_{\mathrm{E}}(\mathrm{msec})$ & 22 & 20 & 30 \\
$\mathrm{Z}_{\text {eff }}$ & 1.8 & 3 & 1 \\
\hline
\end{tabular}




\section{DESCRIPTION OF EXPERIMENTAL CONDITIONS}

The vacuum vessel of ISX-A was constructed of welded 304L stainless steel with no insulating break. Metal vacuum seals were used throughout, except for Viton seals in several gate valves and on several laser windows. All Viton seals were prebaked in a vacuum oven. The vacuum vessel consisted of nine rectangular box-shaped sections connected by . circular bellows. . Each of the box (or diagnostic) sections contained diagnostic ports on the top, bottom, and outside. Figure 1 shows the. location of a titanium evaporator, gas puffer, and bottom movable toroidal limiter, which were located in each of the nine diagnostic sections. Note that the titanium evaporators were shielded so that titanium was deposited mainly on the top of the vessel, as required by the impurity flow reversal experiment. Except for the last two weeks of operation, a11:nine bottom limiters were made of stainless steel and. were uriented.along the toroidal magnetic field. In addition to the bottom limiters, three 1-in.-diam poloidal stainless steel bar limiters, insulated from the vacuum liner, were located in one diagnostic section.

Among the diagnostics ${ }^{10}$ on ISX-A were a scanable Thomson scattering system, a single-channel-microwave interferometer, a:multichord visual spectrometer, both normal- and grazing-incidence ultraviolet spectrometers, sott.x-ray detectors, PIN diude $\mathrm{x}$-ray munituls, a mass-selectable chargc exchange analyzer, and a Langmuir probe. A quadrupole mass analyzer, operated by a small computer.via CAMAC, was used for gas analysis: A sample transfer system was also attached, which allowed small specimens to be positioned inside ISX-A and withdrawn under vacuum for Auger analysis. ${ }^{3}$

\section{VACUUM CONDITIONS, $z_{\text {eff }}$, AND RECYCLING}

Residual gas analysis (RGA) scans of particles with charge-to-mass ratios of 1-50 were routinely made several times each day using a quadrupole mass analyzer. These scans were taken starting $15 \mathrm{sec}$ after a shot. The data were processed in a small computer and plotted on a logarithmic scale in units of partial pressure above background. After several weeks of operation, it became evident from viewing these scans 
ORNL/OWG/FED 78-272

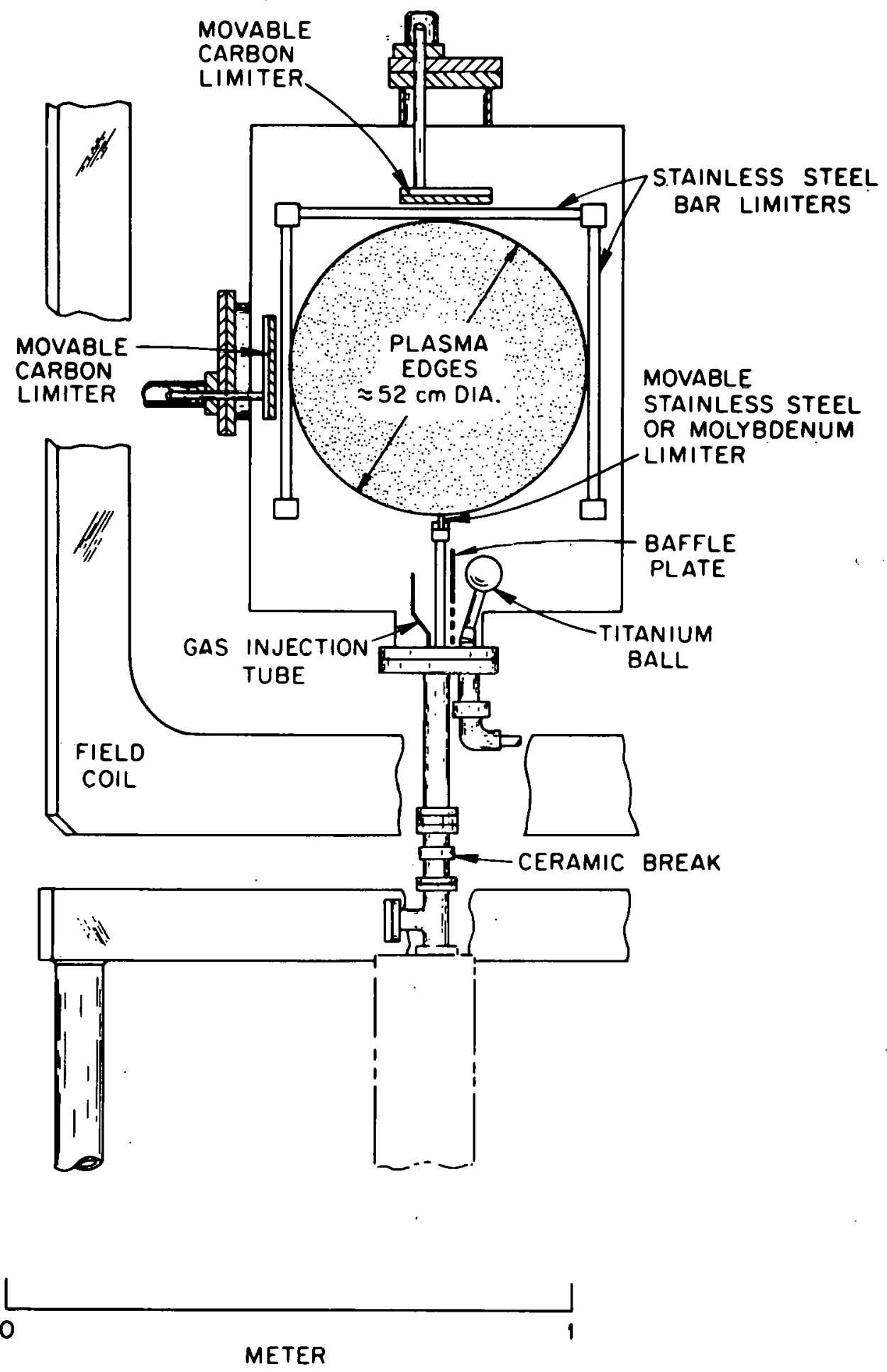

Fig. 1. Cross section of the ISX-A vacuum chamber showing the position of several limiters. 
that the measured values of $\mathrm{Z}_{\text {eff }}$ were proportional to the total partial pressure of contaminant gases. This relationship is shown quantitatively in Fig. 2, where $Z_{\text {eff }}$ values, as determined by the plasma conductivity and $\mathrm{T}_{\mathrm{e}}(\mathrm{r})$ profiles, are plotted against $\mathrm{N}_{\mathrm{I}} / \mathrm{N}_{\mathrm{H}}\left(\mathrm{N}_{\mathrm{I}}\right.$ is the number of impurity atoms in the residual gas scan, and $\mathrm{N}_{\mathrm{H}}$ is the number of hydrogen atoms). It is not clear, a priori, that such a proportionality should exist. However, because the low $\mathrm{Z}$ impurities carbon, oxygen, and nitrogen were the principal contributors to $\mathrm{Z}_{\text {eff }}$ in ISX-A, and because these impurities formed gases (such as $\mathrm{CH}_{4}, \mathrm{C}_{2} \mathrm{H}_{4}, \mathrm{CO}, \mathrm{H}_{2} \mathrm{O}$ ) which remained after each discharge, this result is perhaps not too surprising. For $z_{\text {eff }}<2$, the relationship between $\mathrm{RGA}$ scans and $\mathrm{z}_{\text {eff }}$ is not totally clear. Th1s

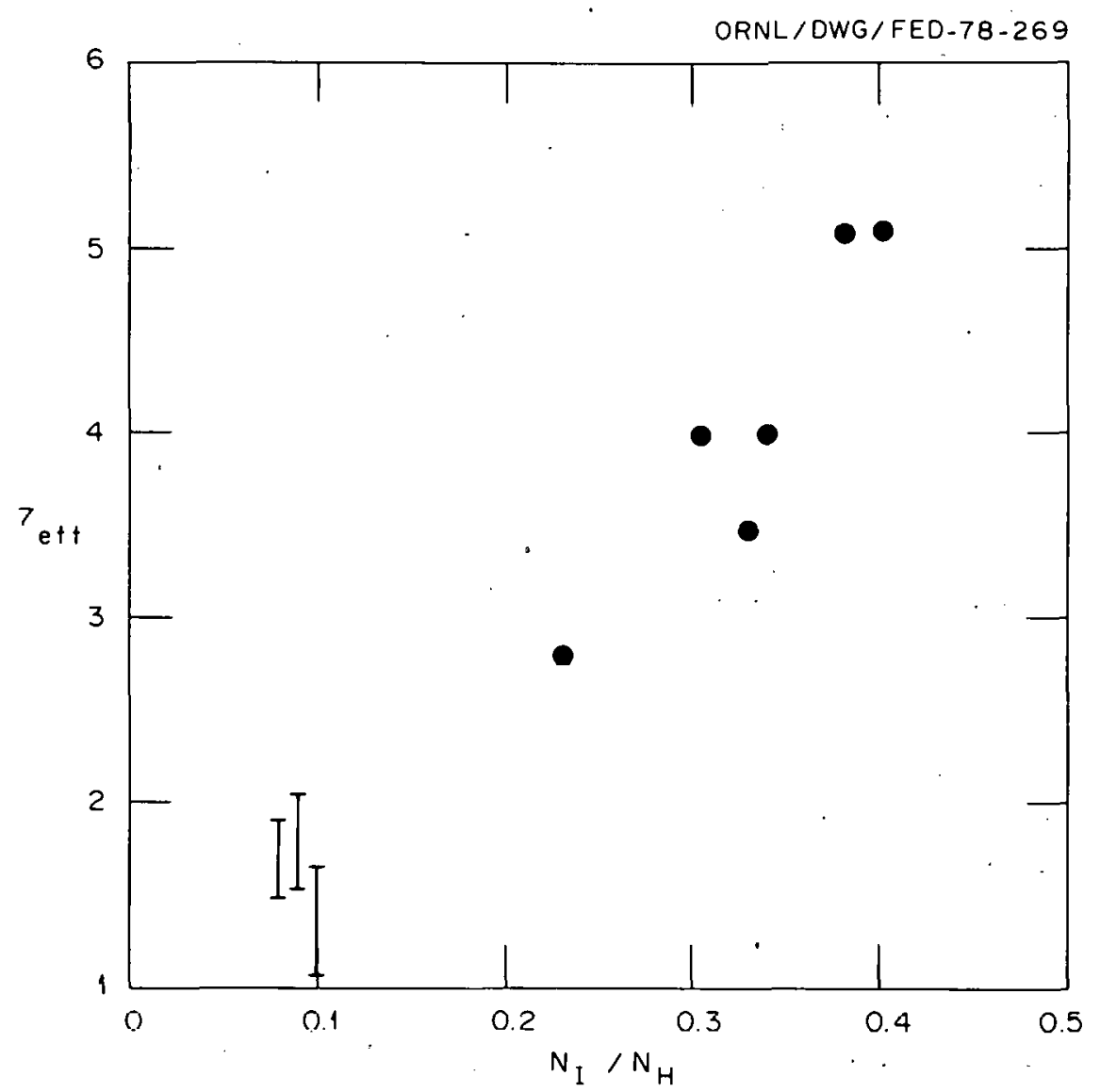

Fig. 2. A comparison of $\mathrm{Z}_{\text {eff }}$, as determined from conductivity and $\mathrm{T}_{\mathrm{e}}(\mathrm{r})$ profiles, with $\mathrm{N}_{\mathrm{I}} / \mathrm{N}_{\mathrm{H}}$. The $\mathrm{Z}_{\text {eff }}$ values in the lower three points have an indicated range as a result of $\mathrm{z}_{\text {eff }}$ variations during a discharge. 
may be because heavy: metals. or plasma turbulence played a role in determining $z_{\text {eff }}$ at low levels. Little correlation between $z_{\text {eff }}$ and base pressure was observed.

Discharge cleaning in hydrogen gas was routinely practiced prior to December 12, 1977 and for five weeks thereafter. The cleaning discharges consisted of 0.5 -msec-long pulses, applied at the rate of $120 / \mathrm{sec}$ in a toroidal field of $200 \mathrm{G}$. Breakdown was assisted by a 1-GHz low power ( $250 \mathrm{~W}$ ) microwave source. This procedure produced a cold plasma with electron temperatures estimated spectroscopically to be from 9 to $18 \mathrm{eV}$. Th1s cleaning procedure was sometimes varied to allow $1-\mathrm{sec}$ or shorter bursts followed by $1-5$ sec of pumping. As a by-product of discharge cleaning, the bellows sections were heated to $160^{\circ} \mathrm{C}$ by currents running through the liner while the box sections remained cool.

The ultimate vacuum attained after hydrogen discharge cleaning was $8 \times 10^{-8}$ torr (gage pressure), and hydrogen was the principal residual gas. The pumping speed of the system was restricted by conductance limits to about 250 liters/sec. Values of $Z_{\text {eff }}$ steadily decreased during the five weeks of discharge cleaning after December 12, 1977, reaching $\mathrm{Z}_{\text {eff }}=1.6$. The principal contaminant gases were $\mathrm{CH}_{4}, \mathrm{CO}$, and $\mathrm{H}_{2} \mathrm{O}$, each contributing less than $10^{-8}$ torr to the background partial pressure. The resulting tokamak discharges exhibited relatively low impurity radiation levels. Table 2 lists preliminary data for the fraction of the ohmic input power radiated by the most abundant plasma impurities. Present uncertainties in analysis of these data imply a $50 \%$ possible error in the results.

Titanium gettering was the principal method of wall conditioning used during the last seven weeks of ISX-A experiments. The initial effect of titanium evaporation was that the ultimate base pressure decreased by a factor of ten, and the carbon and oxygen radiation levels decreased by a factor of three. At first titanium was evaporated after each shot. While this titanium decreased the base pressure, RGA scans $15 \mathrm{sec}$ after the next discharge showed that the $\mathrm{CH}_{3}$ and $\mathrm{CH}_{4}$ peaks increased by an order of magnitude, but that other impurity gases remained unchanged. Without further titanlum evaporation these contamination levels and the value of 
Table 2, ISX: power, radiated to the wall

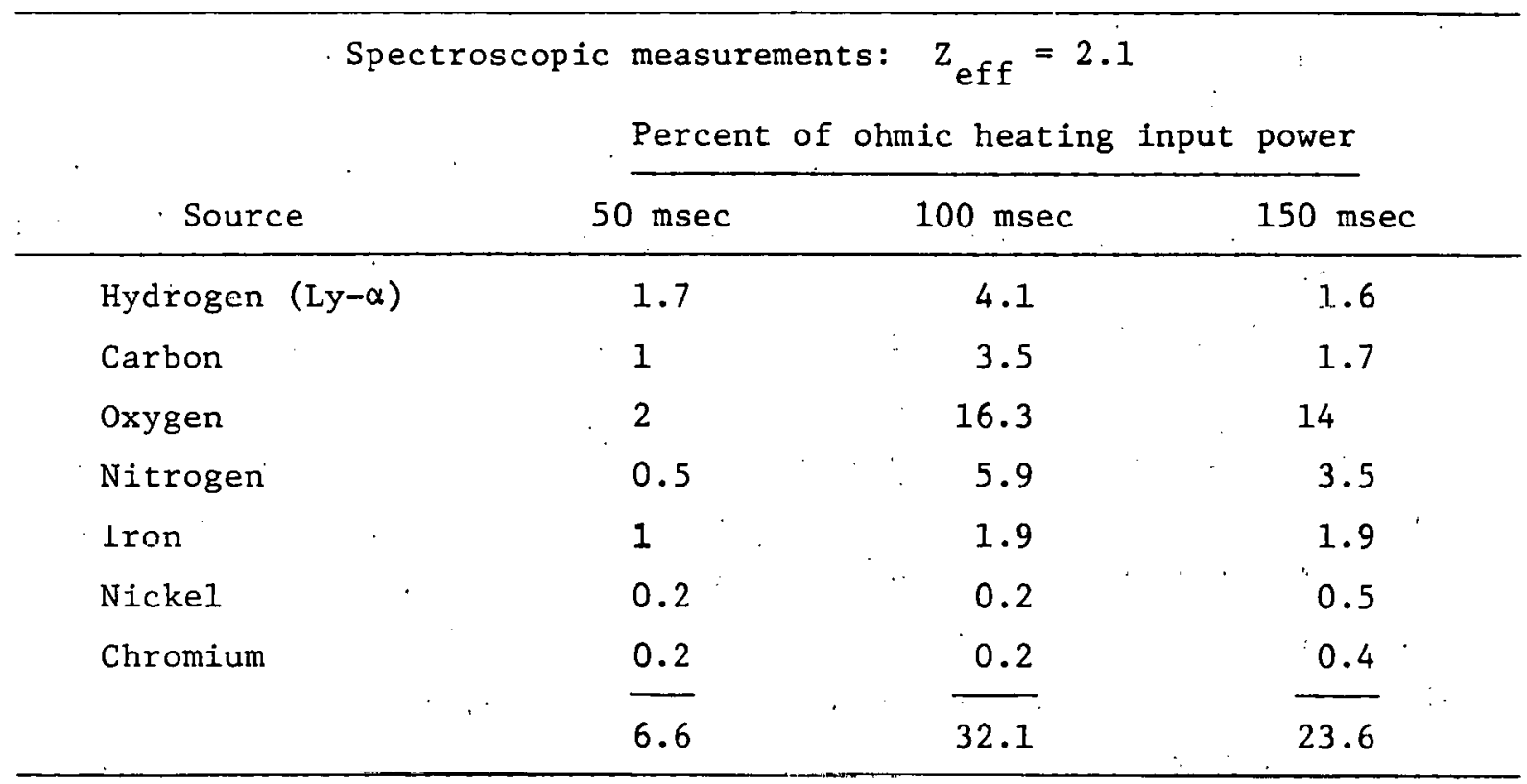

$Z_{\text {eff }}$ remained fairly constant, regardless of the number of shots. Because of this constancy, it became common practice to evaporate titanium only infrequently between shots and at the end of a day's run. The lowest values of $Z_{\text {eff }}$ achieved with titanium evaporacion approached 1.0, and wlll deuterium puffing, energy concalnment thes reached 30 msec.

Table 3 1ists $O \mathrm{VI}, \mathrm{H}$, and $\mathrm{C}$ III radiation for several different discharge sequences. The plasma density was not constant during these experiments, so different shot sequences cannot be directly compared. However, the general trend is clear; lower $z_{\text {eff }}$ values imply more hydrogen radiation and relatively less emission from C III and $O$ VI. The increase in the emission of hydrogen light is particularly striking for $Z_{\text {eff }}=1.1$.

The fraction of the total input power reaching the walls for discharges with different $z_{\text {eff }}$ values is shown in Fig. 3. These data were derived from a pyroelectric detector, and each trace represents an average over several shots. In comparison with spectroscopy data, the radiometer measurements show a larger fraction of the ohmic heating power reaching the wall than was indicated by the intensities of impurity lines, as given in Table 2. Typically, half as much power was radiated to the walls as compared to similar ORMAK discharges. 10 
Table 3. Impurity emission rates

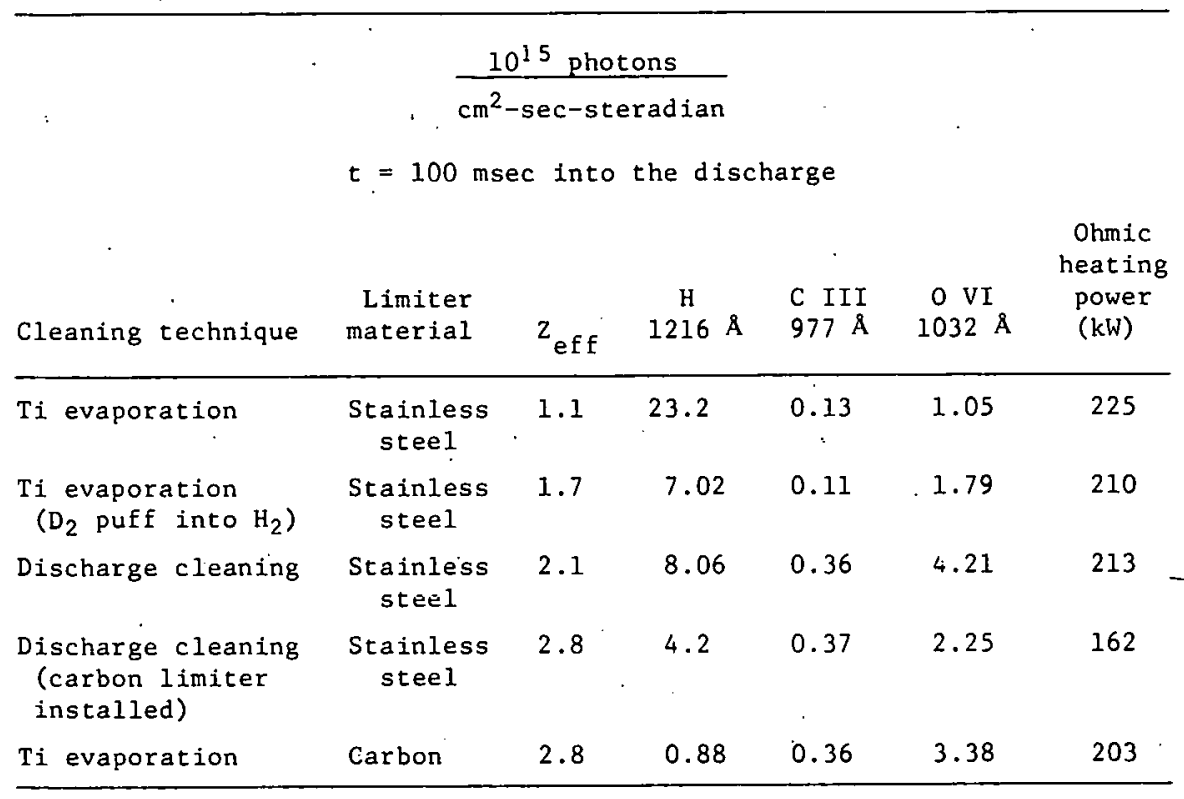

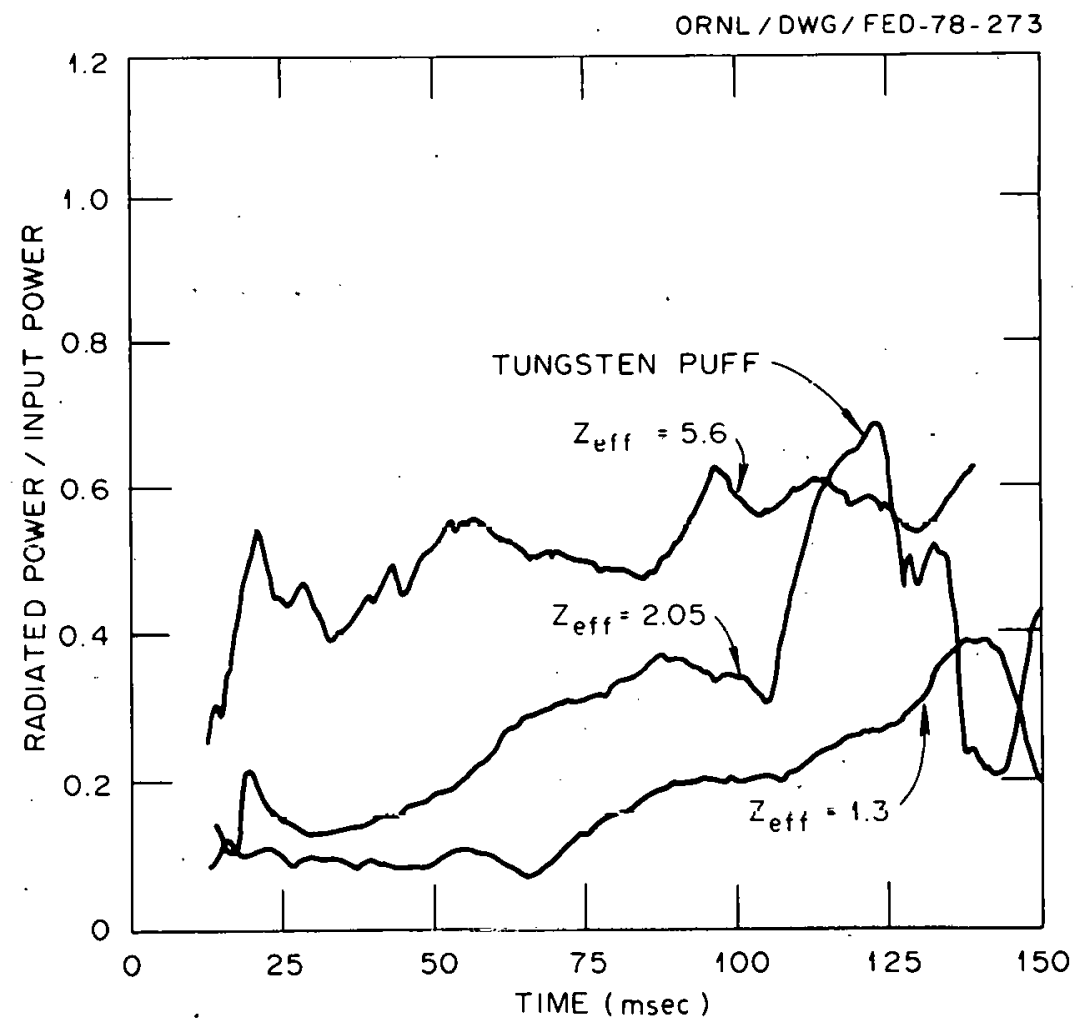

Fig. 3. Fraction of the input power which was radiated to the wall, as observed by a pyroelectric detector. The middle trace shows the result of puffing tungsten atums inlo lhe discharge at $t=100$ msec. 
Although hydrogen was usually the working gas, deuterium was introduced during three different periods of ISX-A operation. Figure 4 gives data from RGA scans of $\mathrm{H}_{2}$, $\mathrm{HD}$; and $\mathrm{D}_{2}$ taken $15 \mathrm{sec}$ after a number of shots. Starting just after a deuterium run the $D_{2}$ partial pressure decayed over several hundred shots, reaching a partial pressure of $<2 \%$ of the total. Much more deuterium was contained in the HD molecule, which never fell below $20 \%$ of the total pressure. This implied a considerable wall holdup and recycling of deuterium. A large amount of deuterium was present in the evaporated titanlum layers, as indicated by a rise in the $\mathrm{D}_{2}$ mass peak with each heating of the box sections during titanfum evaporation. This accounts for the scatter in the data between shots 400 and 700. Similarly, with the reintroduction of deuterium after several hundred hydrogen shots, a considerable amount of hydrogen remained in the vacuum system.

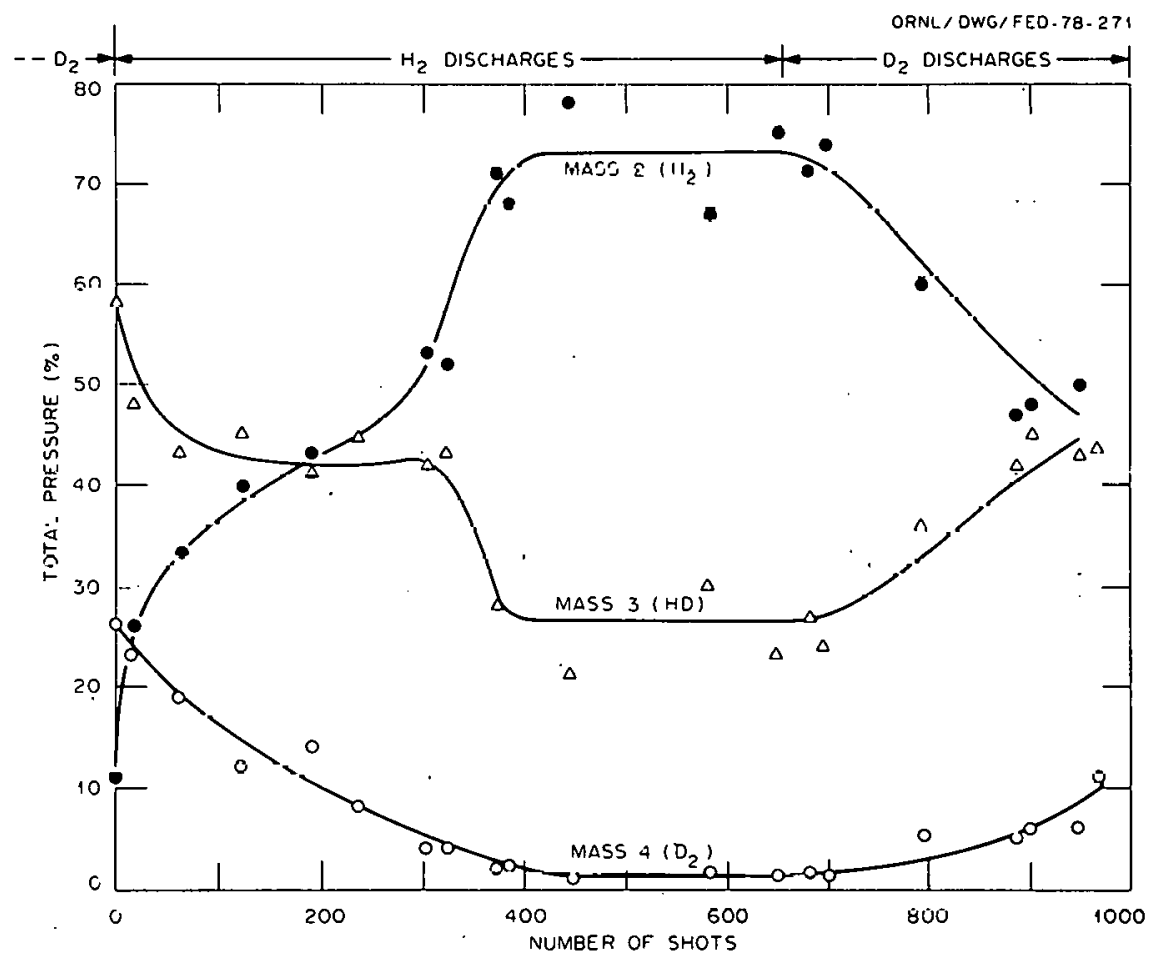

Fig. 4. Variation of the fractional partial pressures of masses 2, 3 , and 4 with $\mathrm{H}_{2}$ and $\mathrm{D}_{2}$ as the working gases. Titanium evaporation was used during the time period in which these shots were taken. Data. were taken starting $15 \mathrm{sec}$ after the completion of tokamak discharges. 


\section{LIMITER EXPERIMENTS}

For all except the last two weeks of operation, stainless steel limiters were used exclusively in ISX-A. With two weeks of experiments remaining, carbon limiters were inserted in a top, bottom, and outside port of one diagnostic section. (Two of these limiters are shown in Fig. 1; a third limiter located in a bottom port is not shown.) A11 three limiters were adjustable from a distance of $2.5 \mathrm{~cm}$ in the shadow of the stainless steel limiter to $5 \mathrm{~cm}$ into the plasma. All three carbon limiters were made of ATJ-S graphite and contained tungsten heaters wrapped on alumina spools which were in turn inserted inside the graphite. In addition, a molybdenum limiter was substituted for one of the bottom retractable stainless steel limiters.

The stainless steel limiters performed remarkably well throughout the life of ISX-A. As may be noted from Table 2, metal contamination was not a serious problem. Upon removal of the stainless steel bars, three distinct types of limiter damage were noted (as shown in Fig. 5). The outside limiter experienced some melting at the center. Pitting and melting due to runaway electrons were mainly observed on the sides of the top limiter. Arc tracks were observed on all limiters, particularly the inside limiter. There was ample evidence of arcing near the insulators at the ends of each rod.

The carbon limiters were baked to above $400^{\circ} \mathrm{C}$ upon installation in ISX-A, having also been previously vacuum baked. Immediately after installation the carbon contaminatinn levels and $\mathrm{z}_{\text {eff }}$ increased, and plasma discharges were irreproducible. Values of $z_{\text {eff }}$ slowly decreased with tokamak operation, as shown in Fig. 6. However, plasmas bounded by the carbon 1 imiter never exhibited $Z_{\text {eff }}$ below 2.8. A detailed comparison of plasma parameters on the last day of operation (see Table 1) shows only small differences between stainless steel and carbon limiter shols, although the elcctron temperature and density profiles were somewhat broader using the carbon limiters. Table 3 shows that the emission of hydrogen light was considerably reduced when the carbon limiter was inserted. RGA scans showed an enhancement in hydrocarbon contaminants throughout the time the carbon limiters were in ISX-A. When the bottom 

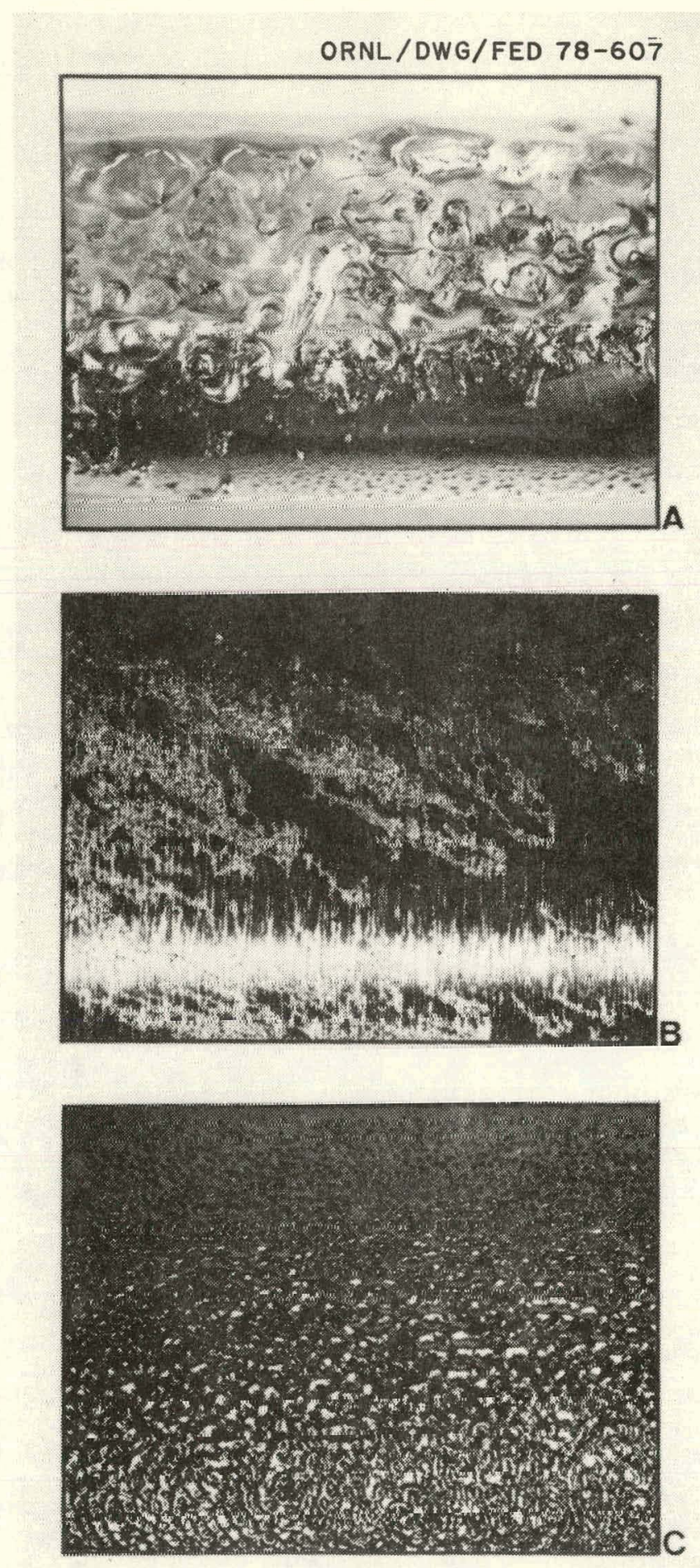

Fig. 5. Three types of limiter damage to the stainless steel bars. (a) Surface melting at the center of the outside bar. (b) Arc tracks, observed generally and particularly on the inner bar. (c) Limiter damage to the side of the top bar caused by runaway electrons melting the surface at localized points. The relative magnifications of (a) to (b) and (c) are $1: 4.1: 1.7$. 


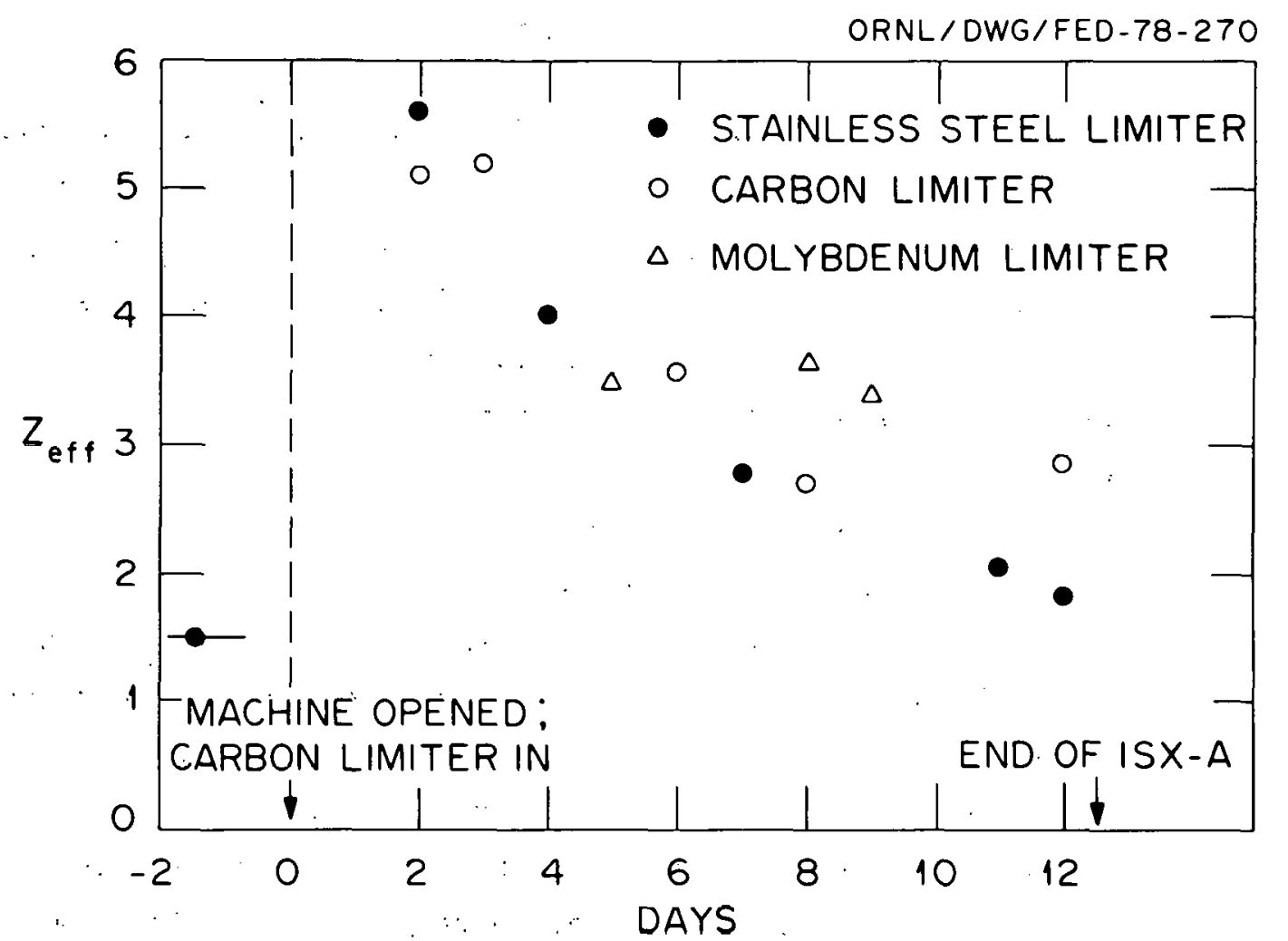

Fig. 6. $\mathrm{Z}_{\text {eff }}$ as a function of days before and after installation of the carbon and molybdenum limiters. $z_{\text {eff }}$ values are given for stainless steel, molybdenum, and carbon limiters.

carbon limiter was heated to $620^{\circ} \mathrm{C}$ in the presence of plasma discharges, no increase in the residual methane gas pressure of $9 \times 10^{-7}$ torr was observed. Considerable evidence of arcing was found on the graphite after removal of the limiters.

With the molybdenum limiter extended into the plasma, discharges could not reproducibly be run with densities above $1.5 \times 10^{13} \mathrm{~cm}^{-3}$, and so comparisons with other limiters were inconclusive. Tungsten atoms were puffed into the plasma via'a laser blowoff system to simulate the effect of the tungsten limiter in ORMAK. 11 With the introduction of $\leqslant 10^{16}$ tungsten atoms (or less than $0.1 \%$ of the total number of electrons), the electron temperature profile became hollow, the voltage increased, and the radiation to the wall increased by $100 \%$. This latter effect is illustrated in Fig. 3. 


\section{CONCLUSIONS}

ISX-A proved to be a very reliable and reproducible tokamak. Using stainless steel limiters, low values of $\mathrm{z}_{\text {eff }}$ were achieved both with discharge cleaning $\left(z_{\text {eff }}=1.6\right)$ and titanium evaporation $\left(z_{\text {eff }} \cong 1.0\right)$. Line radiation and radiometer measurements confirmed that the level of impurity contamination was low. The principal contaminants were carbon, nitrogen, and oxygen, with metals contributing relatively little to the radiated power. Energy containment times were exceptionally l,ong, reaching $\tau_{\mathrm{F}}=30 \mathrm{msec}$ at a toroidal field of $13 \mathrm{kG}$ :

- Discharge cleaning was the preferred mode of wall conditioning. Using titanium evaporation along with stainless steel limiters, it was possible to open the vacuum system to air one day and to have reproducible discharges the next day. However, there was much hydrogen and deuterium holdup in the titanium, as evidenced by the slow changeover in the residual gases when $\mathrm{H}_{2}$ was substituted for $\mathrm{D}_{2}$. As titanium layers became thicker over a several week period, outgassing with titanium evaporation became more and more of a problem.

The introduction of the carbon limiters into ISX-A and their subsequent bake-out caused $z$ eff to rise to the highest values observed, $z_{\text {eff }}=5.6$. During the twelve days of operation after their introduction, $Z_{\text {cff }}$ steadily dropped, but $z_{\text {eff }}$ values with carbon limiters were slightly higher than comparable discharges with stainless steel limiters. Considerable evidence of arcing was observed on both the carbon and the stainless steel limiters. When small amounts of tungsten were puffed into the plasma, the radiated power doubled and the temperature profile became hollow.

Values of $z_{\text {eff }} \geq 2.0$ were found to bo proportional to the amount of contaminants in residual gases. immediately after a discharge, as observed by RGA scans. There was little correlation between $\mathrm{Z}_{\text {eff }}$ and base pressure.

\section{ACKNOWLEDGMENTS}

We would like to thank H. E. Ketterer, V. J. Meece, T. F. Rayburn, and W. L. Redmond for operating ISX-A. R. D. Overbey was responsible for computer programing. Design, construction, and experimental assistance 
with the carbon limiters were provided by R. A. Ellis, Jr., V. Corso, J. L. Cecchi, and M. Nishi of the Princeton Plasma Physics Laboratory. Finally, we would like to thank J. Sheffield, L. A. Berry, and O. B. Morgan for their support of this project.

\section{REFERENCES}

1. R. J. Colchin and T. C. Jernigan, J. Nuc1. Mater. 63, 83 (1976).

2. K. H. Burre11, Phys. Fluids 19, 401 (1976), and references cited therein.

3. L. C. Emerson, R. E. Clausing, and L. Heatherly, Proc. 3rd Int. Conf. on PZasma Surface Interactions in Controlzed Fusion Devices, April 1978, Culham, England (to be published).

4. TFR Group, Proc. Int. Symp. on Plasma Wall Interactions, p. 3 (1977).

5. P. Ginot et al., Proc. 3rd Int. Conf. on Plasma Surface Interactions in Corlrrolzed Fusion Devices, April 1978, Culham, England (to be published).

6. T. Hirayama et al., Proc. 3rd Int. Conf. on Plasma Surface Interactions in Controlled Fusion Devices, April 1978, Culham, England (to be published).

7. S. Konoshima et al., Proc. 3rd Int. Conf. on Plasma Surface Interactions in Controlled Fusion Devices, April 1978, Culham, England (to be published).

8. S. A, Conhen et al., Proc. 3rd Int. Conf. on Plasma Surface Interactions in Controlled Fusion Devices, April 1978, Culham, England (to be published).

9. S. A. Cohen, Proc. 2nd Conf. on Surface Effects in Controlled Fusion Devices, p. 65 (1976).

10. R. J. Colchin et a1., J. Nuc1. Mater. 63, 74 (1976).

11. R. C. Ist.er, R. V. Neidigh, and R. D. Cowen, Phys. Lett. 63A, 295 (1977). 


\section{THIS PAGE}

\section{WAS INTENTIONALLY LEFT BLANK}




\author{
ONRL/TM-6446 \\ Dist. Category UC-20 a, c, f
}

INTERNAL DISTRIBUTION
1. B. R. Appleton
2. L. A. Berry
3. C. E. Bush
4. J. D. Callen
5. R. J. Colchin
6. A. C. Cooper
7. R. E. Clausing
8. J. L. Dunlap
9. P. H. Edmonds
10. L. C. Emerson
11. A. C. England
12. C. A. Foster
13. J. T. Hogan
14. H. C. Howe, Jr.
15. R. C. Isler
16. T. C. Jernigan
17. G. G. Kelley
18. H. E. Ketterer
19. P. W. King
20. R. A. Langley
21. J. F. Lyon
22. D. H. McNeill
23. J. T. Mihalczo
24. S. L. Milora

25. 0. B. Morgan

26. M. Murakami

27. R. V. Neidigh

28. G. H. Neilson.

29. V. K. Paré

30. H. Postma

31. J. A. Rome

32. M. W. Rosenthal

33. J. Sheffield

34. J. E. Simpkins

35. D. A. Spong

36. D. W. Swain

37. J. B. Wilgen

38. W. R. Wing

39. R. A. Zuhr

40-41. Central Research Library

42. Document Reference Section

43-44. Laboratory Records Department

45. Laboratory Records, ORNL-RC

46. ORNL Patent office

47. Fusion Energy Division Library

48. Fusion Energy Division

Communications Center

\title{
EXTERNAL DISTRIBUTION
}

49. D. J. Anthony, General Electric Company, Building 23, Room 290, 1 River Road, Schenectady, NY 12345.

50. A. M. Budker, Nuclear Physics Institute; Siberian Ácademy of Sciences, -Novosibirsk 90, U.S.'S.R:

51. K. H. Burre11, General Atomic Company, P.0. Box 81608, San Diego, CA 92138

52. Centre de Recherches en Library, Physique des Plasmas, 21 Avenue des Bains, 1007 Lausanne, Switzerland

53. J. F. Clarke, Office of Fusion Energy, Department of Energy, WashlingLon, DC 20545 .

54. R. W. Conn, Department of Nuclear Engineering, University of Wisconsin, Madison, WI 53706 .

55. CTR Reading Room, c/o Jay Borris, Plasma Physics Division, Naval Research Laboratories, Washington, DC $\cdot 20390$

56. CTR Reading Room, Department of Physics and Astronomy, University of Maryland, College Park, MD 20742 
57. CTR Reading Room, c/o B. D. Fried, Physics Department, University of California, Los Angeles, CA 90024

58. CTR Reading Room, c/o Roy Gould, California Institute of Technology, Pasadena, CA 91103

59. CTR Reading Room, c/o R. Gross, Plasma Research Laboratory, Columbia University, New York, NY 10027

60. Research Laboratory of Electronics, Attention J. Hewitt, Document Room 36-412, Massachusetts Institute of Technology, Cambridge, MA 02139

61. K. W. Hil1, Princeton Plasma Physics Laboratory, Princeton University, P.O. Box 451, Princeton, NJ 08540

62. T. Hiraoka, Japan Atomic Energy Research Institute, Tokai, Ibaraki, Japan

63. R. L. Ilirsch, Exxon Research and Englneering Company, P.0. Box 101 , Florham Park, NJ 07932

64. T. Hsu, Office of Fusion Energy, Department of Energy, Washington, DC 20545

65. P. Hubert, Service de Recherches sur 1a Fusion Controlee, Centre d'Etudes Nucleaires, Fontenay-aux-Roses (Seine), Republic of France

66. H. E. Knoepfel, Laboratori Gas Ionizzati, Associazione Euratom-CNEN, Casella Postale N. 65, Frascati (Roma), Italy

67. Librarian, Contrólled Thermonuclear Research Library, Lawrence Livermore Laboratory, University of California, P.0. Box 808, Livermore, CA 94550

68. Librarian, Culham Laboratory, United Kingdom Atomic Energy Authority, Abingdon, Berkshire, England

69. Librarian, Department of Physics and Astronomy, University of Iowa, Iowa City, IA 52240

70. Librarian, Max-Planck-Institut für Plasmaphysik, 8046 Garching bei Munchen, Federal Republic of Germany

71. Librarian, Plasma Physics Laboratory, c/o H. P. Furth, Princeton University, P.O. Box 451, Princeton, N.J 08540

72. Librarian, Q Division Library, Los Alamos Scientific Laboratory, P.O. Box 1663, Los Alamos, NM 87544

73. S. Mirnov, Kurchatov Institute of Atomic Energy, 46 Ulitsa Kurchatov, P.O. Box 3402 , Moscow, U.S.S.R.

74. Plasma Laboratory Reading Room, Massachusetts Institute of Technology, Room 20A-222, Cambridge, MA 02139

75. Plasma Physics Group, Department of Engineering Physics, Australian National University, P.O. Box 4, Canberra, A.C.T. 2600, Australia

76. CTR Reading Room, c/o T. Kammash, 103 Research Administration Building, North Campus, University of Michigan, Ann Arbor, MI 48105

77. CTR Reading Room, c/o D. W. Kerst, Department of Physics, Sterling Hal1, University of Wisconsin, Madison, WI 53706

78. CTR Reading Room, c/o W. B. Thomson, Physics Department, University of California, San Diego, CA 92037

79. N. A. Davies, Office of Fusion Encrgy, Department of Energy, Washington, DC 20545

80. J. C. DeBoo, General Atomic Company, P.o. Box 81608, San Diego, CA 92138 
81. Department of Nuclear Engineering Sciences, 202 Nuclear Science Center, University of Florida, Gainesville, FL 32611

82. Director, Technical Library, Defense Atomic Support Agency, Sandia Base, Albuquerque, NM 87115

83. A. M. Dupas, Documentation S.I.G.N., Department de la Physique du Plasma et de la Fusion Controlee, Association Euratom-CEA sur la Fusion, Centre d'Etudes Nucleaires, BP 85 Centre du Tri, 38041

84. E. S. Ensberg, General Atomic Company, P.0. Box 81608, San Diego, CA 92138

85. C. R. Finfgeld, Office of Fusion Energy, Department of Energy, Washington, DC 20545

86. H. K. Forsen, Exxon Nuclear Co., Inc., 777 106th Avenue, NE, Bellevue, WA 98004

87. H. H. Fleischmann, Department of Applied Physics, Cornell University, Ithaca, NY 14853

88. H. Grad, Courant Institute, New York University, 251 Mercer Street, New York, NY 10012

89. I. Gverdsiteli, Physico-Technical Institute, Georgian Academy of Sciences, Sukhumi, U.S.S.R.

90. M. S. Rabinovich, P. N. Lebedev Institute of Physics of the U.S.S.R. Academy of Sciences, Moscow, U.S.S.R.

91. Research Information Center, Institute of Plasma Physics, Nagoya University, Nagoya, Japan

92. F. R. Scutt, Electrlc Power Research Institute, 3412 Hillview Avenue, P.0. Box 10412, Palo Alto, CA 94303

93. Thermonuclear Laboratory, Kurchatov Institute of Atomic Energy, 46 Ulitsa Kurchatova, P.O. Box 3402, Moscow, U.S.S.R.

94. Thermonuclear Library, Japan Atomic Energy Research Institute, Tokai, Naka, Ibaraki, Japan

95: Versator Group, c/o G. Bekefi, Department of Physics, Massachusetts Institute of Technology, Cambridge, MA 02139

96. F. Waelbroeck, Institut für Plasmaphysik, KFA, Postfach 1913, D-517 Jülich 1, GMBH, Federal Republic of Germany

97. G. H. Wolf, Institut für Plasmaphysik, KFA, Postfach 1913, D-517 Jülich 1, GMBH, Federal Republic of Germany

98. K. M. Zwilsky, Office of Fusion Energy, Department of Energy, Washington, DC 20545

99. Director, Research and Technical Support Division, DOE-ORO, P.O. Box E, Oak Ridge, TN 37830

100-397. Given distribution as shown in TID-4500, Magnetic Fusion Energy (Distribution Category UC-20 a, c, and $\mathrm{f}$ : Plasma Systems, Reactor Materials, and Experimental Plasma Physics) 